\title{
2. GEOCHEMISTRY OF LAVAS FROM HOLE 896A ${ }^{1}$
}

\author{
T.S. Brewer, ${ }^{2}$ W. Bach,${ }^{3}$ and H. Furnes ${ }^{4}$
}

\begin{abstract}
Hole 896A is a second deep basement hole within oceanic crust formed at the Costa Rica Rift, which penetrated $\sim 290 \mathrm{~m}$ of the lava sequence. The lava sequence is dominated by pillow lavas and massive flows, although minor breccias and two thin dikes were also recovered. The basalts are predominantly plagioclase + olivine phyric tholeiites, although in one section of the hole (353.1-392.1 mbsf) clinopyroxene is also present as phenocrysts.

Geochemically, the basalts are strongly depleted, moderately evolved mid-ocean ridge basalts. All the basalts are similar to the Groups D and D' basalts recovered from nearby Hole 504B, located approximately $1 \mathrm{~km}$ to the north of Hole 896A. None of the Hole 896A basalts have chemical signatures similar to the more evolved Group M or T basalts recovered from Hole 504B.

A significant geochemical feature of the Hole 896A basalts is that the drilled section can be divided into a number of discrete chemical units. The uppermost unit, Group A $(<340 \mathrm{mbsf})$ has a relatively uniform composition, although the more primitive lavas occur at the top of this unit. Below $340 \mathrm{mbsf}$, the chemostratigraphy is characterized by sawtoothed profiles, produced by fractionation (plagioclase + olivine + clinopyroxene) followed by replenishment of the magma chamber. Near to the base of the current drilled section, the lowermost unit (Unit E) is geochemically similar to Unit B, except that the more primitive lavas occur at the top of this unit. Unit E is separated from the remainder of the drilled section by a thin highly depleted unit (Unit D).

The new geochemical data suggest that magmatism at the Costa Rica Rift developed in a dynamic system, where melts were produced from a common source by similar degrees of melting, but higher level processes (i.e., fractional crystallization and or mixing) generated discrete magma batches. This variation in the chemistry of the individual magma batches probably reflects a difference in the crustal level of the individual magma chambers and/or the timing of replenishment of the magma chambers.
\end{abstract}

\section{INTRODUCTION}

In the equatorial east Pacific, the Cocos-Nazca Spreading Center consists of the Galapagos, Ecuador and Costa Rica Rifts (Dick, Erzinger, Stokking, et al., 1992). This rift system was initiated approximately $27 \mathrm{Ma}$ ago, by the formation of the Galapagos Triple Junction (Hey et al., 1977; Lonsdale and Klitgord, 1978), which produced a triangular wedge, the Galapagos Gore (Holden and Dietz, 1972; Dick, Erzinger, Stokking, et al., 1992). The Costa Rica Rift is the easternmost of the three rift segments, and separates the Cocos and Nazca plates. This rift system spreads asymmetrically at an intermediate rate (half rate of $3.6 \mathrm{~cm} / \mathrm{yr}$ to the south and $3.0 \mathrm{~cm} / \mathrm{yr}$ to the north).

With the drilling of Ocean Drilling Program Hole 896A, two deep basement holes (i.e., Holes 504B and 896A) now penetrate oceanic crust formed at the Costa Rica Rift. Hole 504B, the deepest basement hole in oceanic crust so far drilled, is located approximately $200 \mathrm{~km}$ to the south of the Costa Rica Rift, in 5.9 Ma old crust. Hole 896A is located approximately $1 \mathrm{~km}$ to the south of Hole 504B in crust $\sim 2.8$ $\times 10^{4} \mathrm{yr}$ older than at Hole 504B. The distribution of the two holes provides an excellent opportunity to evaluate the nature of the magmatic processes operating at the Costa Rica Rift system and to evaluate if and how these processes varied in a relatively short period of time (i.e., $<30,000 \mathrm{yr}$ ).

Alt, J.C., Kinoshita, H., Stokking, L.B., and Michael, P.J. (Eds.), 1996. Proc. ODP, Sci, Resuits, 148: College Station, TX (Ocean Drilling Program),

${ }^{2}$ Borehole Research, Department of Geology, University of Leicester, Leicester. LE1 7RH, United Kingdom. tsb5@leicester.ac.uk

GeoForschungsZentrum Potsdam, Projektbereich 4.2, Telegrafenberg A50, D-14473 Potsdam. Federal Republic of Germany (present address: Universität Potsdam. Institut für Geowissenschaften, Postfach 601553, D-14415 Potsdam, Federal Republic of Germany) wbach@gfz-potsdam.de

${ }^{4}$ Geological Institute, University of Bergen, Allegaten 41, N-5007 Bergen, Norway. Harald.Furnes@geol.uib.no
Hole $896 \mathrm{~A}$ is located $\sim 1 \mathrm{~km}$ southeast of Hole 504B on a bathymetric high overlying a basement topographic high (Alt, Kinoshita, Stokking, et al., 1993). Basement was first reached at $179 \mathrm{~m}$ below seafloor (mbsf), but the hole was cored from only 195.1 to 469 mbsf (Alt, Kinoshita, Stokking, et al., 1993). The actual depth of the basement may be more accurately constrained following detailed analysis of the geochemical wireline logs (T.S. Brewer and P.K. Harvey, pers. comm., 1993). Within the drilled section, core recovery averaged $26.9 \%$. Pillow lavas $(57 \%)$ and massive flows $(38 \%)$ dominant the cored material, with breccias $(5 \%)$ and two small dikes accounting for the remainder of the material. The basalts are sparsely to highly phyric tholeiites, with plagioclase and olivine dominating the phenocryst assemblages, although between 353.1 and $392.1 \mathrm{mbsf}$, clinopyroxene is present as a phenocryst phase (Alt, Kinoshita, Stokking, et al., 1993). With the exception of the glassy pillowed rims, the majority of the rocks are slightly altered $(<10 \%)$ and variably veined (Alt, Kinoshita, Stokking, et al., 1993).

\section{GEOCHEMISTRY}

In all 109 samples which span the entire cored interval (Table 1) were analyzed from Hole 896A. All samples were crushed and then ground in agate; pressed powder pellets were used for the trace element analysis, major elements were determined on glass fusion beads, and major and trace elements were determined by X-ray fluorescence spectrometry at Nottingham University (Table 1) following identical procedures to those described in Alt, Kinoshita, Stokking, et al. (1993). The exceptions to this were in the determination of $\mathrm{Nb}$ and $\mathrm{Rb}$, because in the data of Alt, Kinoshita, Stokking, et al. (1993) many of the samples were close to or below the level of detection for both of these elements. In an attempt to improve the quality of the $\mathrm{Nb}$ and $\mathrm{Rb}$ data, the count times were increased by a factor of 10 and each sample was analyzed 6 times. This procedure lowered the detection 
Table 1. Geochemical analysis of basalts from Hole 896A.

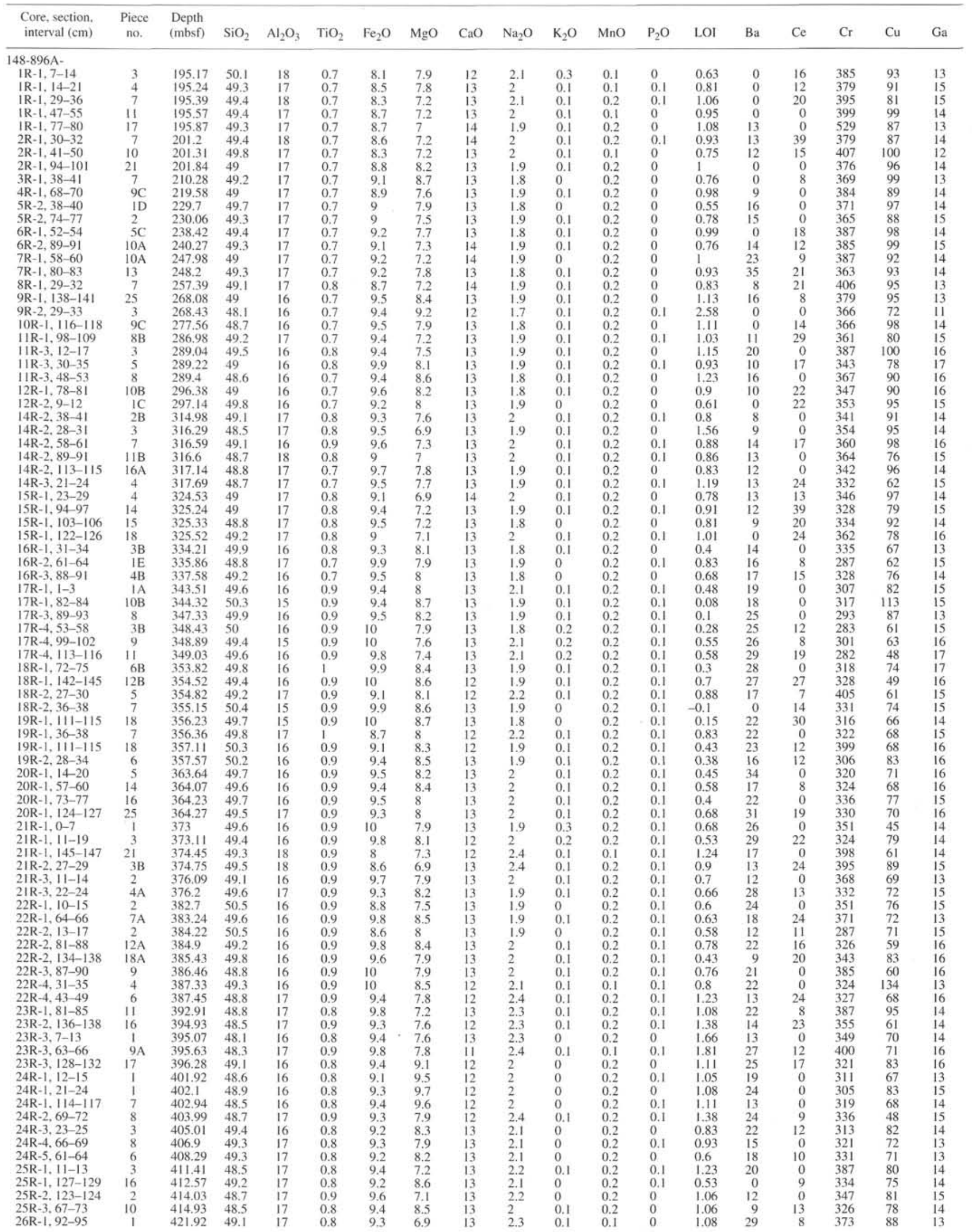


Table 1 (continued).

\begin{tabular}{|c|c|c|c|c|c|c|c|c|}
\hline $\begin{array}{l}\text { Core, section, } \\
\text { interval }(\mathrm{cm})\end{array}$ & $\begin{array}{c}\text { Piece } \\
\text { no. }\end{array}$ & $\mathrm{La}$ & $\mathrm{Nb}$ & $\mathrm{Ni}$ & $\mathrm{Pb}$ & $\mathrm{Rb}$ & $\mathrm{S}$ & $\mathrm{Sc}$ \\
\hline $148-896 \mathrm{~A}-$ & & & & & & & & \\
\hline IR-1, 7-14 & 3 & 0 & 0.76 & 181 & 5 & 2.38 & 812 & 48 \\
\hline$|R-1| 4-2 \mid$, & 4 & 0 & 0.47 & 125 & 7 & 2.99 & 454 & 48 \\
\hline IR-1, 29-36 & 7 & 0 & 0 & 189 & 0 & 0 & 1931 & 45 \\
\hline $1 \mathrm{R}-1,47-55$ & 11 & 0 & 0.8 & 169 & 6 & 1.77 & 1007 & 49 \\
\hline IR-1, 77-80 & 17 & 0 & 0.12 & 162 & 0 & 2.18 & 1207 & 45 \\
\hline $2 \mathrm{R}-1,30-32$ & 7 & 0 & 0 & 170 & 0 & 0 & 1672 & 41 \\
\hline $2 \mathrm{R}-1,41-50$ & 10 & 0 & 0.63 & 174 & 7 & 2.18 & 952 & 47 \\
\hline $2 \mathrm{R}-1,94-101$ & 21 & 7 & 0.75 & 179 & 4 & 3.16 & 806 & 40 \\
\hline $3 R-1,38-41$ & 7 & 0 & 0.66 & 182 & 9 & 2.08 & 922 & 40 \\
\hline $4 \mathrm{R}-1,68-70$ & $9 \mathrm{C}$ & 0 & 0.49 & 175 & 8 & 2.11 & 1060 & 44 \\
\hline $5 R-2,38-40$ & ID & 0 & 0.71 & 178 & 5 & 2.59 & 710 & 42 \\
\hline $5 R-2,74-77$ & 2 & 0 & 0.74 & 167 & 4 & 1.77 & 1042 & 45 \\
\hline $6 \mathrm{R}-1,52-54$ & $5 \mathrm{C}$ & 0 & 0.87 & 163 & 0 & 2.63 & 1135 & 41 \\
\hline $6 \mathrm{R}-2,89-91$ & $10 \mathrm{~A}$ & 8 & 0.8 & 167 & 5 & 3.02 & 1077 & 37 \\
\hline $7 \mathrm{R}-1,58-60$ & $10 \mathrm{~A}$ & 0 & 0.77 & 163 & 8 & 1.78 & 978 & 41 \\
\hline $7 R-1,80-83$ & 13 & 0 & 0.75 & 164 & 4 & 1.85 & 1006 & 46 \\
\hline $8 \mathrm{R}-1,29-32$ & 7 & 0 & 0.86 & 164 & 8 & 2.53 & 1015 & 50 \\
\hline $9 R-1,138-141$ & 25 & 0 & 0.94 & 159 & 3 & 2.44 & 978 & 46 \\
\hline $9 \mathrm{R}-2,29-33$ & 3 & 0 & 0.91 & 162 & 5 & 4.08 & 473 & 40 \\
\hline $10 R-1.116-118$ & $9 \mathrm{C}$ & 0 & 0.61 & 154 & 0 & 2.87 & 2761 & 45 \\
\hline $11 R-1,98-109$ & $8 B$ & 0 & 0 & 155 & 0 & 0 & 1568 & 41 \\
\hline IIR-3, $12-17$ & 3 & 0 & 0.9 & 148 & 5 & 2.59 & 1080 & 46 \\
\hline $11 \mathrm{R}-3,30-35$ & 5 & 0 & 0 & 136 & 0 & 0 & 166 & 36 \\
\hline $11 \mathrm{R}-3,48-53$ & 8 & 0 & 0.6 & 161 & 5 & 2.95 & 804 & 44 \\
\hline $12 \mathrm{R}-1.78-81$ & $10 \mathrm{~B}$ & 7 & 0.43 & 169 & 6 & 3.56 & 298 & 43 \\
\hline $12 \mathrm{R}-2,9-12$ & IC & 6 & 0.69 & 166 & 4 & 1.79 & 1590 & 39 \\
\hline $14 R-2,38-41$ & $2 \mathrm{~B}$ & 0 & 0.92 & 156 & 7 & 2.39 & 797 & 42 \\
\hline $14 R-2,28-31$ & 3 & 0 & 0.73 & 152 & 6 & 2.13 & 835 & 46 \\
\hline $14 R-2,58-61$ & 7 & 0 & 0.99 & 109 & 4 & 2 & 1249 & 50 \\
\hline $14 \mathrm{R}-2,89-91$ & $11 \mathrm{~B}$ & 0 & 0.59 & 148 & 0 & 2.38 & 1856 & 47 \\
\hline $14 \mathrm{R}-2,113-115$ & $16 \mathrm{~A}$ & 0 & 0.52 & 151 & 7 & 3.17 & 140 & 39 \\
\hline $14 \mathrm{R}-3,2 \mathrm{l}-24$ & 4 & 0 & 0 & 148 & 0 & 0 & 309 & 40 \\
\hline $15 \mathrm{R}-1,23-29$ & 4 & 4 & 0.04 & 162 & 7 & 2.54 & 868 & 44 \\
\hline $15 \mathrm{R}-1.94-97$ & 14 & 0 & 0 & 147 & 0 & 0 & 1185 & 42 \\
\hline $15 R-1,103-106$ & 15 & 0 & 0.4 & 143 & 9 & 2.21 & 1038 & 48 \\
\hline $15 \mathrm{R}-1,122-126$ & 18 & 0 & 0 & 149 & 0 & 0 & 1988 & 46 \\
\hline $16 \mathrm{R}-1,31-34$ & $3 \mathrm{~B}$ & 0 & 0.75 & 164 & 7 & 2.62 & 147 & 38 \\
\hline $16 R-2,61-64$ & IE & 0 & 0.35 & 148 & 0 & 1.88 & 92 & 37 \\
\hline $16 \mathrm{R}-3,88-91$ & $4 \mathrm{~B}$ & 4 & 0.51 & 161 & 4 & 1.66 & 94 & 38 \\
\hline $17 \mathrm{R}-1,1-3$ & IA & 4 & 0.71 & 121 & 5 & 3.46 & 695 & 45 \\
\hline $17 \mathrm{R}-1,82-84$ & $10 B$ & 0 & 0.4 & 183 & 10 & 3.06 & 921 & 43 \\
\hline $17 \mathrm{R}-3,89-93$ & 8 & 0 & 0.61 & 132 & 6 & 3.53 & 571 & 44 \\
\hline $17 \mathrm{R}-4,53-58$ & $3 \mathrm{~B}$ & 0 & 0 & 103 & 0 & 0 & 433 & 46 \\
\hline $17 R-4,99-102$ & 9 & 0 & 0.61 & 82 & 3 & 5.08 & 102 & 47 \\
\hline $17 \mathrm{R}-4,113-116$ & 11 & 0 & 0 & 105 & 0 & 0 & 110 & 46 \\
\hline $18 \mathrm{R}-1,72-75$ & $6 \mathrm{~B}$ & 6 & 0.71 & 120 & 4 & 3 & 1347 & 45 \\
\hline $18 \mathrm{R}-1,142-145$ & 12B & 0 & 0 & 100 & 0 & 0 & 1500 & 47 \\
\hline $18 \mathrm{R}-2,27-30$ & 5 & 0 & 0.62 & 109 & 0 & 2.21 & 2214 & 47 \\
\hline $18 R-2,36-38$ & 7 & 0 & 0.71 & 129 & 7 & 1.66 & 1565 & 45 \\
\hline $19 \mathrm{R}-1,111-115$ & 18 & 0 & 0.35 & 121 & 7 & 2.17 & 1195 & 43 \\
\hline $19 R-, 36-38$ & 7 & 0 & 0.76 & 127 & 0 & 1.63 & 1792 & 47 \\
\hline $19 \mathrm{R}-1.111-115$ & 18 & 0 & 0.78 & 120 & 0 & 2.48 & 1662 & 47 \\
\hline $19 R-2,28-34$ & 6 & 0 & 0.62 & 181 & 4 & 3.97 & 502 & 38 \\
\hline $20 \mathrm{R}-1,14-20$ & 5 & 0 & 0.9 & 102 & 8 & 2.98 & 989 & 41 \\
\hline $20 \mathrm{R}-1,57-60$ & 14 & 0 & 0.76 & 122 & 0 & 1.86 & 1632 & 44 \\
\hline $20 \mathrm{R}-1.73-77$ & 16 & 5 & 0.54 & 93 & 5 & 2.41 & 1149 & 39 \\
\hline $20 \mathrm{R}-1,124-127$ & 25 & 0 & 0.54 & 118 & 0 & 2.72 & 1781 & 45 \\
\hline 2 IR-1, 0-7 & 1 & 0 & 0.74 & 98 & 0 & 7.46 & 126 & 42 \\
\hline $21 \mathrm{R}-1,11-19$ & 3 & 0 & 0.86 & 109 & 8 & 5.23 & 581 & 46 \\
\hline $21 \mathrm{R}-1,145-147$ & 21 & 0 & 0.52 & 98 & 0 & 3.43 & 2161 & 48 \\
\hline $21 R-2,27-29$ & $3 \mathrm{~B}$ & 0 & 0.68 & 138 & 7 & 3.41 & 550 & 39 \\
\hline $21 \mathrm{R}-3,1 \mathrm{I}-14$ & 2 & 0 & 0.35 & 113 & 0 & 3.12 & 1244 & 41 \\
\hline $21 R-3,22-24$ & $4 \mathrm{~A}$ & 0 & 0.83 & 118 & 7 & 2.43 & 1252 & 39 \\
\hline $22 \mathrm{R}-1,10-15$ & 2 & 0 & 0.78 & 124 & 0 & 1.46 & 1008 & 42 \\
\hline $22 \mathrm{R}-1,64-66$ & $7 \mathrm{~A}$ & 0 & 0.79 & 120 & 7 & 2.49 & 993 & 46 \\
\hline $22 \mathrm{R}-2,13-17$ & 2 & 0 & 0.65 & 115 & 0 & 2 & 473 & 45 \\
\hline $22 \mathrm{R}-2,81-88$ & $12 \mathrm{~A}$ & 7 & 0.52 & 102 & 5 & 4.06 & 121 & 38 \\
\hline $22 \mathrm{R}-2,134-138$ & $18 \mathrm{~A}$ & 0 & 0.99 & 122 & 2 & 3.49 & 650 & 42 \\
\hline $22 \mathrm{R}-3,87-90$ & 9 & 0 & 0.78 & 105 & 0 & 3.91 & 124 & 40 \\
\hline $22 \mathrm{R}-4,31-35$ & 4 & 0 & 0.47 & 106 & 7 & 3.52 & 425 & 41 \\
\hline $22 \mathrm{R}-4,43-49$ & 6 & 9 & 0.34 & 110 & 9 & 3.87 & 125 & 43 \\
\hline $23 R-1,81-85$ & 11 & 0 & 0.47 & 126 & 8 & 3.83 & 183 & 39 \\
\hline $23 R-2,136-138$ & 16 & 0 & 0.45 & 127 & 0 & 5.19 & 147 & 37 \\
\hline $23 R-3,7-13$ & 1 & 0 & 0.55 & 149 & 2 & 4.87 & 146 & 39 \\
\hline $23 R-3,63-66$ & $9 \mathrm{~A}$ & 0 & 0.86 & 93 & 0 & 9.71 & 205 & 43 \\
\hline $23 \mathrm{R}-3,128-132$ & 17 & 0 & 0.73 & 157 & 9 & 1.52 & 1904 & 27 \\
\hline $24 \mathrm{R}-1,12-15$ & I & 0 & 0.67 & 150 & 0 & 1.29 & 1408 & 40 \\
\hline $24 \mathrm{R}-1,2 \mathrm{I}-24$ & i & 0 & 0.63 & 157 & 6 & 1.53 & 1911 & 35 \\
\hline $24 \mathrm{R}-1,114-117$ & 7 & 0 & 0.41 & 147 & 0 & 1.93 & 1682 & 36 \\
\hline $24 \mathrm{R}-2,69-72$ & 8 & 0 & 0.45 & 129 & 0 & 7.28 & 108 & 40 \\
\hline $24 \mathrm{R}-3,23-25$ & 3 & 0 & 0.78 & 162 & 4 & 2.07 & 1243 & 35 \\
\hline $24 \mathrm{R}-4,66-69$ & 8 & 0 & 0.83 & 166 & 0 & 1.44 & 384 & 34 \\
\hline $24 \mathrm{R}-5,6 \mathrm{I}-64$ & 6 & 0 & 0.84 & 157 & 0 & 1.39 & 1364 & 32 \\
\hline $25 \mathrm{R}-1,11-13$ & 3 & 0 & 0.58 & 187 & 0 & 2.76 & 1333 & 41 \\
\hline $25 \mathrm{R}-1,127-129$ & 16 & 0 & 0.56 & 178 & 0 & 2.05 & 1710 & 39 \\
\hline $25 \mathrm{R}-2,123-124$ & 2 & 0 & 0.73 & 192 & 4 & 2.19 & 938 & 43 \\
\hline $25 \mathrm{R}-3,67-73$ & 10 & 0 & 0.74 & 181 & 0 & 2.76 & 1770 & 42 \\
\hline $26 \mathrm{R}-1,92-95$ & 1 & 0 & 0.69 & 198 & 9 & 2.95 & 792 & 41 \\
\hline
\end{tabular}


Table 1 (continued).

\begin{tabular}{|c|c|c|c|c|c|c|c|c|c|c|c|c|c|c|c|c|c|c|}
\hline $\begin{array}{l}\text { Core, section, } \\
\text { interval }(\mathrm{cm})\end{array}$ & $\begin{array}{c}\text { Piece } \\
\text { no. }\end{array}$ & $\begin{array}{l}\text { Depth } \\
\text { (mbsf) }\end{array}$ & $\mathrm{SiO}_{2}$ & $\mathrm{Al}_{2} \mathrm{O}_{3}$ & $\mathrm{TiO}_{2}$ & $\mathrm{Fe}_{2} \mathrm{O}$ & $\mathrm{MgO}$ & $\mathrm{CaO}$ & $\mathrm{Na}_{2} \mathrm{O}$ & $\mathrm{K}_{2} \mathrm{O}$ & $\mathrm{MnO}$ & $\mathrm{P}_{2} \mathrm{O}$ & LOI & $\mathrm{Ba}$ & $\mathrm{Ce}$ & $\mathrm{Cr}$ & $\mathrm{Cu}$ & $\mathrm{Ga}$ \\
\hline $26 \mathrm{R}-1,134-139$ & 1 & 422.34 & 49.2 & 17 & 0.9 & 9.5 & 6.7 & 13 & 2.3 & 0.1 & 0.2 & 0 & 0.88 & 32 & 0 & 394 & 93 & 14 \\
\hline $26 \mathrm{R}-2,88-89$ & 2 & 423.39 & 48.4 & 17 & 0.9 & 9.6 & 7 & 13 & 2.2 & 0 & 0.2 & 0 & 1.34 & 38 & 7 & 367 & 81 & 14 \\
\hline $27 \mathrm{R}-1,22-25$ & $i$ & 430.72 & 48.9 & 17 & 0.9 & 9.9 & 7.2 & 13 & 2.2 & 0.1 & 0.2 & 0 & 1 & 14 & 0 & 364 & 89 & 15 \\
\hline $27 \mathrm{R}-1,71-75$ & i & 431.21 & 49.8 & 16 & 0.8 & 9.8 & 8.4 & 13 & 1.9 & 0.3 & 0.2 & 0 & 0.4 & 29 & 15 & 378 & 74 & 14 \\
\hline $27 \mathrm{R}-1,86-92$ & 10 & 431.36 & 48.7 & 16 & 0.6 & 9.1 & 9 & 13 & 1.8 & 0.4 & 0.2 & 0.1 & 1.26 & 13 & 0 & 367 & 64 & 11 \\
\hline $27 R-1,101-104$ & $12 \mathrm{~B}$ & 431.51 & 49.2 & 16 & 0.8 & 9.3 & 8.3 & 13 & 1.9 & 0.2 & 0.2 & 0.1 & 0.78 & 12 & 0 & 365 & 68 & 13 \\
\hline $27 \mathrm{R}-2,109-112$ & 2 & 433.04 & 48.9 & 16 & 0.6 & 9.5 & 7.9 & 14 & 1.8 & 0 & 0.2 & 0 & 0.83 & 0 & 18 & 366 & 78 & 15 \\
\hline $27 \mathrm{R}-3,53-58$ & 6 & 433.9 & 48.3 & 16 & 0.7 & 10 & 8.4 & 13 & 1.9 & 0.1 & 0.2 & 0 & 1.41 & 9 & 12 & 366 & 67 & 13 \\
\hline $28 \mathrm{R}-1.54-58$ & 1 & 440.54 & 48.7 & 16 & 0.6 & 9.7 & 8.5 & 13 & 1.7 & 0.1 & 0.2 & 0 & 0.99 & 0 & 11 & 395 & 71 & 14 \\
\hline $28 \mathrm{R}-1.83-87$ & 16 & 440.83 & 48.2 & 17 & 0.6 & 9.8 & 8.1 & 13 & 1.7 & 0.3 & 0.2 & 0 & 1.05 & 0 & 0 & 374 & 70 & 14 \\
\hline $28 \mathrm{R}-2,0-7$ & IA & 441.41 & 47.7 & 16 & 0.6 & 9.9 & 9.2 & 13 & 1.6 & 0.1 & 0.2 & 0.1 & 1.65 & 13 & 21 & 340 & 61 & 15 \\
\hline $29 \mathrm{R}-1,0-10$ & i & 449.7 & 50.1 & is & 0.9 & 9.4 & 8.6 & 13 & 2 & 0.2 & 0.2 & 0.1 & 0.25 & 16 & 21 & 324 & 93 & 14 \\
\hline $29 \mathrm{R}-1,49-53$ & i & 450.19 & 50.4 & 15 & 0.8 & 9.8 & 8.8 & 13 & 1.9 & 0.3 & 0.2 & 0.1 & 0.13 & 13 & 0 & 341 & 93 & 14 \\
\hline $29 R-1,98-100$ & 14 & 450.68 & 49.4 & 17 & 0.8 & 8.1 & 7.8 & 13 & 2 & 0 & 0.2 & 0 & 0.91 & 26 & 18 & 328 & 80 & 16 \\
\hline $29 \mathrm{R}-1,123-126$ & $i$ & 450.93 & 50.1 & 16 & 0.8 & 9.1 & 8 & 13 & 2 & 0.2 & 0.2 & 0.1 & 0.35 & 29 & 8 & 384 & 63 & 14 \\
\hline $29 \mathrm{R}-2,1-5$ & 2 & 451.13 & 50.1 & 16 & 0.8 & 9.1 & 8.6 & 13 & 2 & 0.1 & 0.2 & 0 & 0.1 & 15 & 0 & 357 & 106 & 14 \\
\hline $30 \mathrm{R}-1,5-8$ & $i$ & 459.35 & 50 & 16 & 0.8 & 9.3 & 8.4 & 13 & 2.1 & 0.1 & 0.2 & 0.1 & 0.03 & 17 & 20 & 366 & 91 & 15 \\
\hline $30 \mathrm{R}-1,81-86$ & $11 \mathrm{C}$ & 460.11 & 50.1 & 15 & 0.8 & 9.9 & 8.8 & 13 & 2 & 0.2 & 0.2 & 0.1 & 0.33 & is & 0 & 318 & 83 & 14 \\
\hline $30 R-1,103-107$ & 1 & 460.33 & 50.1 & 15 & 0.8 & 10 & 8.6 & 13 & 2 & 0.1 & 0.2 & 0.1 & -0 & 31 & 0 & 368 & 95 & 14 \\
\hline $30 \mathrm{R}-1,137-141$ & i & 460.67 & 50.4 & 15 & 0.8 & 9.5 & 8.7 & 13 & 2 & 0.2 & 0.2 & 0 & 0.08 & 30 & 25 & 346 & 72 & 13 \\
\hline $30 R-2,5-7$ & IA & 460.84 & 49.7 & 15 & 0.8 & 10 & 8.4 & 13 & 2 & 0.2 & 0.2 & 0.1 & 0.2 & 70 & 0 & 326 & 83 & 15 \\
\hline
\end{tabular}

Notes: Major elements are measured in weight percent (wt\%) and trace elements in parts per million (ppm). A value of zero indicates that the element is below the detection limit. LOI $=$ loss on ignition.

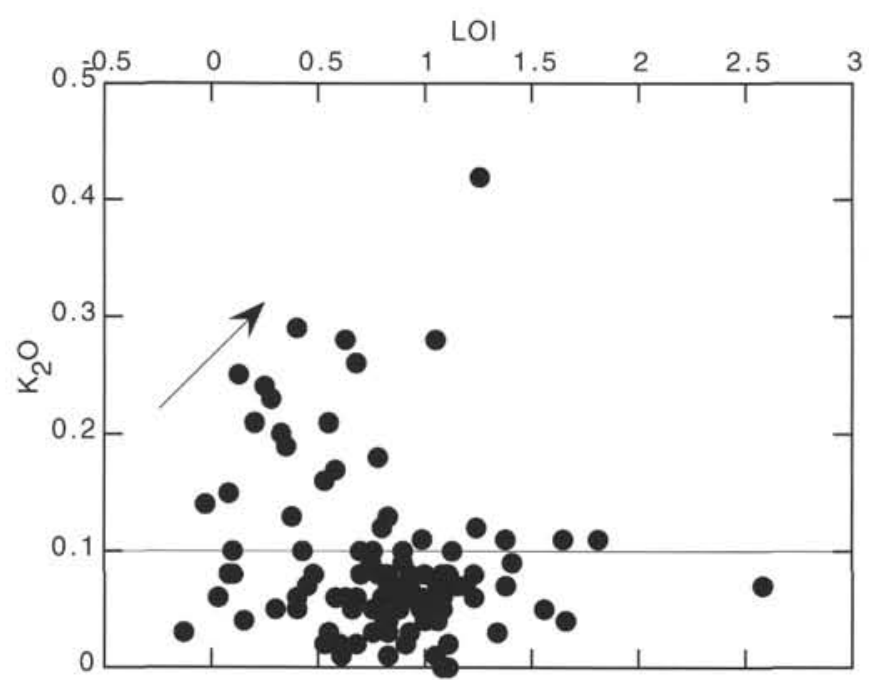

Figure 1. $\mathrm{K}_{2} \mathrm{O}$ vs. loss on ignition (LOI) for Hole $896 \mathrm{~A}$ basalts. Arrow indicates correlation for altered samples $\left(\mathrm{K}_{2} \mathrm{O}>0.1 \%\right)$. Samples with $\mathrm{K}_{2} \mathrm{O}<$ $0.1 \%$ are classified as unaltered.

limit (detection limit, $0.1 \mathrm{ppm}$ ) and increased the precision of the analysis $( \pm 5 \%)$. The increased quality of these data is essential in the petrogenetic discussion as both $\mathrm{Rb}$ and $\mathrm{Nb}$ are incompatible elements that have been used to both classify Hole 504B basalts (Autio and Rhodes, 1983; Kempton et al., 1985) and to establish the nature of the source of oceanic magmas in general (Sun and McDonough, 1989).

Before discussing the igneous geochemistry of Hole 896A, the effects of alteration must be evaluated because these effects can often mimic magmatic processes (Hellman et al., 1977).

\section{BULK-ROCK ALTERATION}

All samples used in the present study were selected so as to exclude obvious signs of alteration (i.e., veined material); however, within Hole 896A all the basalts are passively altered, even though this alteration $(<10 \%)$ is limited (Alt, Kinoshita, Stokking, et al.,

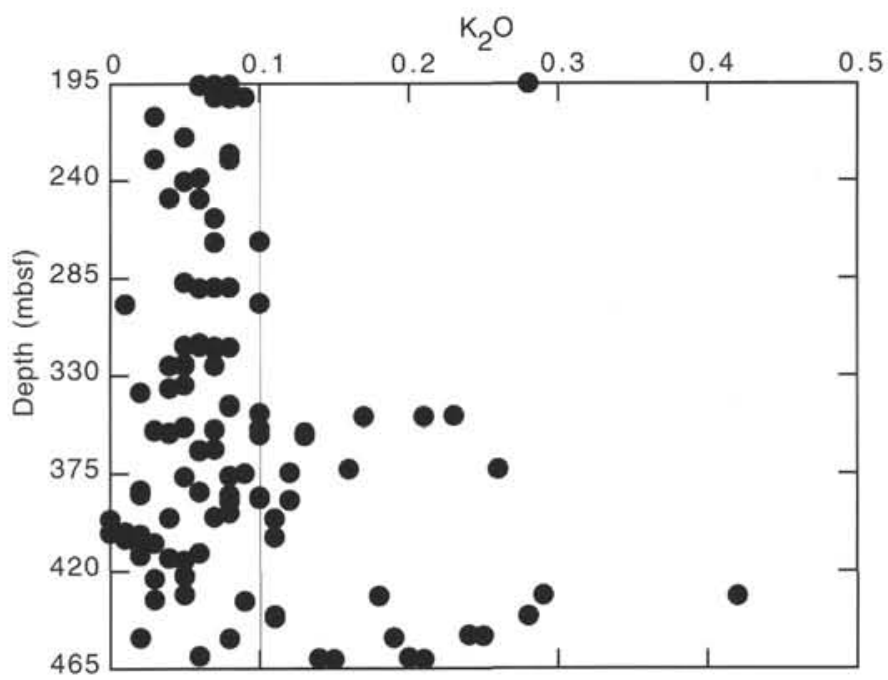

Figure 2. Downhole variation of $\mathrm{K}_{2} \mathrm{O}$ in Hole $896 \mathrm{~A}$. Basalts with $\mathrm{K}_{2} \mathrm{O}>$ $0.10 \%$ are classified as altered.

1993). In Hole 896A, bulk-rock alteration of the basalts is limited to three types of halos (Alt, Kinoshita, Stokking, et al., 1993); the halos show no significant variation with depth. However, oxidized alteration correlates with the distribution of massive basalts (Alt, Kinoshita, Stokking, et al., 1993). Because massive units are more abundant below 340 mbsf, oxidative alteration is greater below 340 mbsf (Alt, Kinoshita, Stokking, et al., 1993).

The effects of alteration on the bulk-rock chemistry of pillow basalts have been studied extensively in Hole 504B by Kempton et al. (1985). These authors concluded that $\mathrm{K}$ and $\mathrm{Sr}$ are mobile in the upper pillow lava section where seawater interaction is greatest. Emmermann (1985) divided the alteration in the pillow lavas into upper oxidative and lower nonoxidative zones, with $\mathrm{K}_{2} \mathrm{O}, \mathrm{S}$, and iron oxidation ratio $\left(\mathrm{Fe}_{2} \mathrm{O}_{3} / \mathrm{Fe}_{2} \mathrm{O}_{3} \mathrm{~T}\right)$ being the most effective measures to discriminate between these zones.

In the pillow lavas from Hole 504B, the positive correlation between $\mathrm{K}_{2} \mathrm{O}$ and LOI was interpreted as $\mathrm{K}$ mobility during the low temperature hydration of the basalts (Dick, Erzinger, Stokking, et al., 
Table 1 (continued).

\begin{tabular}{|c|c|c|c|c|c|c|c|c|c|c|c|c|c|c|c|}
\hline $\begin{array}{l}\text { Core, section, } \\
\text { interval }(\mathrm{cm})\end{array}$ & $\begin{array}{c}\text { Piece } \\
\text { no. }\end{array}$ & La & $\mathrm{Nb}$ & $\mathrm{Ni}$ & $\mathrm{Pb}$ & $\mathrm{Rb}$ & $\mathrm{S}$ & $\mathrm{Sc}$ & $\mathrm{Sr}$ & Th & $\mathrm{U}$ & V & $\mathrm{Y}$ & $\mathrm{Zn}$ & $\mathrm{Zr}$ \\
\hline $26 R-1,134-139$ & 1 & 0 & 0.02 & 201 & 6 & 2.35 & 1210 & 44 & 72 & 2 & 0 & 222 & 22 & 66 & 50 \\
\hline $26 \mathrm{R}-2,88-89$ & 2 & 0 & 0.51 & 185 & 6 & 1.7 & 946 & 37 & 86 & 4 & 1 & 208 & 20 & 64 & 48 \\
\hline $27 \mathrm{R}-1,22-25$ & 1 & 0 & 0.72 & 163 & 4 & 2.98 & 885 & 39 & 69 & 0 & 0 & 216 & 24 & 65 & 49 \\
\hline $27 R-1,71-75$ & 1 & 0 & 0.96 & 168 & 3 & 8.1 & 327 & 39 & 65 & 0 & 0 & 216 & 21 & 58 & 43 \\
\hline $27 \mathrm{R}-1.86-92$ & 10 & 0 & 0.25 & 146 & 0 & 3.79 & 1510 & 38 & 74 & 5 & 0 & 179 & 20 & 45 & 30 \\
\hline $27 \mathrm{R}-1,101-104$ & $12 \mathrm{~B}$ & 0 & 0.75 & 172 & 0 & 4.87 & 846 & 42 & 62 & 5 & 0 & 209 & 23 & 54 & 50 \\
\hline $27 R-2,109-112$ & 2 & 4 & 0.71 & 170 & 6 & 2.26 & 582 & 41 & 69 & 0 & 0 & 200 & 17 & 59 & 32 \\
\hline $27 R-3,53-58$ & 6 & 0 & 0.42 & 174 & 0 & 2.7 & 2129 & 39 & 62 & 4 & 0 & 192 & 19 & 63 & 35 \\
\hline $28 R-1,54-58$ & 1 & 7 & 0.52 & 164 & 5 & 2.95 & 267 & 38 & 74 & 2 & 0 & 201 & 17 & 57 & 32 \\
\hline $28 \mathrm{R}-1.83-87$ & 16 & 0 & 0.82 & 176 & 0 & 3.21 & 522 & 38 & $? ?$ & 5 & 0 & 187 & 18 & 54 & 32 \\
\hline $28 \mathrm{R}-2,0-7$ & IA & 0 & 0.76 & 169 & 0 & 2.75 & 653 & 40 & 62 & 1 & 0 & 177 & 18 & 52 & 37 \\
\hline $29 \mathrm{R}-1,0-10$ & 1 & 0 & 0.63 & 134 & 0 & 5.36 & 214 & 42 & 54 & 3 & 0 & 250 & 28 & 63 & 43 \\
\hline 29R-I, 49-53 & i & 0 & 0.75 & 127 & 5 & 6.86 & 220 & 46 & 54 & 2 & 0 & 249 & 22 & 66 & 47 \\
\hline $29 \mathrm{R}-1,98-100$ & 14 & 0 & 0.66 & 134 & 0 & 1.98 & 1485 & 39 & 63 & 4 & 0 & 212 & 21 & 45 & 47 \\
\hline $29 \mathrm{R}-1,123-126$ & 1 & 0 & 0.61 & 127 & 5 & 4.86 & 135 & 39 & 61 & 0 & 0 & 242 & 23 & 70 & 45 \\
\hline $29 R-2,1-5$ & 2 & 4 & 0.57 & 186 & 7 & 3.16 & 404 & 40 & 60 & 3 & 0 & 229 & 20 & 62 & 47 \\
\hline $30 R-1,5-8$ & 1 & 0 & 0.89 & 137 & 7 & 2.38 & 1001 & 45 & 63 & 2 & 0 & 236 & 24 & 64 & 45 \\
\hline $30 \mathrm{R}-1,81-86$ & $11 \mathrm{C}$ & 0 & 0.84 & 132 & 0 & 5.7 & 686 & 41 & 55 & 6 & 0 & 232 & 26 & 60 & 47 \\
\hline $30 \mathrm{R}-1,103-107$ & 1 & 0 & 0.92 & 123 & 6 & 5.05 & 589 & 42 & 55 & 0 & 0 & 253 & 20 & 65 & 42 \\
\hline $30 \mathrm{R}-1,137-141$ & I & 0 & 1.02 & 155 & 7 & 4.44 & 273 & 41 & 56 & 0 & 0 & 255 & 23 & 65 & 47 \\
\hline $30 \mathrm{R}-2,5-7$ & IA & 0 & 0.63 & 110 & 0 & 5.96 & 682 & 43 & 52 & 3 & 0 & 237 & 26 & 62 & 48 \\
\hline
\end{tabular}

Table 2. Comparison of the geochemistry of the basalts from Holes 504B and 896A.

\begin{tabular}{|c|c|c|c|c|c|c|}
\hline & \multicolumn{4}{|c|}{ Hole 504B } & \multicolumn{2}{|c|}{ Hole $896 \mathrm{~A}$} \\
\hline & Group M & Group D & Group D' & Group T & Upper & Lower \\
\hline $\mathrm{SiO}_{2}$ & 50 & 50.4 & 49.9 & 50.6 & 49.15 & 49.35 \\
\hline $\mathrm{TiO}_{2}$ & 1.37 & 0.92 & 0.92 & 1.09 & 0.74 & 0.85 \\
\hline $\mathrm{Al}_{2} \mathrm{O}_{3}$ & 15.3 & 15.9 & 15.5 & 15.3 & 16.84 & 16.19 \\
\hline $\mathrm{Fe}_{2} \mathrm{O}_{3}$ & 9.95 & 9.87 & 10.1 & 9.86 & 9.15 & 9.48 \\
\hline $\mathrm{MnO}^{\circ}$ & 0.18 & 0.16 & 0.19 & 0.25 & 0.17 & 0.18 \\
\hline $\mathrm{MgO}$ & 8.17 & 8.4 & 8.6 & 8.71 & 7.64 & 8.15 \\
\hline $\mathrm{CaO}$ & 12.5 & 12.5 & 13 & 12.2 & 13.23 & 12.74 \\
\hline $\mathrm{Na}_{2} \mathrm{O}$ & 2.5 & 2 & & 2.15 & 1.89 & 2.02 \\
\hline $\mathrm{K}_{2} \mathrm{O}$ & 0.06 & 0.11 & 0.02 & 0.03 & 0.06 & 0.1 \\
\hline $\mathrm{P}_{2} \mathrm{O}_{2}$ & 0.13 & 0.07 & 0.07 & 0.11 & 0.05 & 0.05 \\
\hline $\mathrm{Rb}$ & $<0.5$ & 1.3 & $<0.5$ & $<0.5$ & 1.9 & 2.8 \\
\hline $\mathrm{Sr}$ & 105 & 64 & 55 & 73 & 67 & 64 \\
\hline $\mathrm{Y}$ & 31.2 & 23.3 & 22.8 & 23.5 & 22 & 24 \\
\hline $\mathrm{Ga}$ & 16.2 & 15.4 & 15.2 & 14.8 & 14.3 & 14.6 \\
\hline $\mathrm{Zr}$ & 103.7 & 47 & 46 & 67 & 43 & 47 \\
\hline $\mathrm{Nb}$ & 2.4 & 0.6 & 0.9 & 4.2 & 0.44 & 0.65 \\
\hline $\mathrm{Zn}$ & 79 & 77 & 80 & 107 & 59 & 61 \\
\hline $\mathrm{Ni}$ & 97 & 117 & 117 & 107 & 159 & 138 \\
\hline $\mathrm{Cr}$ & 257 & 359 & 336 & 342 & 368 & 344 \\
\hline V & 310 & 274 & 263 & 257 & 230 & 232 \\
\hline
\end{tabular}

Notes: Data from Hole 504B taken from Kempton et al. (1985). The basalts from Hole $896 \mathrm{~A}$ have been split into two groups: "Lower" refers to basalts from $>340 \mathrm{mbsf}$, and "Upper" refers to basalts from $<340 \mathrm{mbsf}$.

1992). In Hole 896A, the downhole variation of $\mathrm{K}_{2} \mathrm{O}$ is characterized by localized "spikes," which are more common in the lower part of the hole ( $>340 \mathrm{mbsf}$ ), where oxidative groundmass alteration is more extensive (Alt, Kinoshita, Stokking, et al., 1993). Below 340 mbsf, samples with $\mathrm{K}_{2} \mathrm{O}>0.10 \%$, display a positive correlation between $\mathrm{K}_{2} \mathrm{O}$ and LOI (Fig. 1), where, the LOI values broadly correlate with hydration of the basalts (Alt, Kinoshita, Stokking, et al., 1993). The correlation between LOI and $\mathrm{K}_{2} \mathrm{O}$ therefore, indicates the preferential mobility of $\mathrm{K}$ during this low temperature alteration. Using this relationship, it is evident that altered samples have $\mathrm{K}_{2} \mathrm{O}>0.10 \%$, and that the following pattern to the alteration can be established from the whole rock chemistry:

1. In the upper part (195.1-340 mbsf) alteration effects are limited and the majority of the samples have $\mathrm{K}_{2} \mathrm{O}<0.10 \%$ (Fig. 2).

2. Below 340 mbsf, the $\mathrm{K}_{2} \mathrm{O}$ curve (Fig. 2) contains several spikes that represent regions of more intense low-temperature alteration. These more altered zones are interspersed with "unal- tered" material, suggesting some structural or lithological control to this style of alteration.

Below 340 mbsf in Hole 896A, oxidative alteration of the groundmass, $\mathrm{K}$ mobility, massive units, and breccias all increase (Alt, Kinoshita, Stokking, et al., 1993). The relatively high $\mathrm{K}_{2} \mathrm{O}$ values are restricted to discrete zones, which appear to correlate with the boundaries of the massive units, suggesting the focusing of fluids and alteration along such lithological boundaries. In contrast, the oxidative alteration of the groundmass is common throughout the majority of the lower part of the hole, within which breccias are more abundant (Alt, Kinoshita, Stokking, et al., 1993). The breccias have the highest porosities within the drilled section (Alt, Kinoshita, Stokking, et al., 1993) which allowed more extensive fluid-rock interactions within this part of the hole, resulting in the oxidation of the groundmass of the basaltic material.

In Hole 504B, Emmermann (1985) suggested that $\mathrm{Cu}, \mathrm{Zn}, \mathrm{S}$, and $\mathrm{Mn}$ were also potential discriminators of alteration. However, in Hole $896 \mathrm{~A}$ the lack of correlation between these elements and $\mathrm{K}_{2} \mathrm{O}$ and LOI suggests that these elements have not been greatly effected by low temperature alteration. Therefore, the most effective chemical discriminate of alteration Hole $896 \mathrm{~A}$ is $\mathrm{K}$, which suggests that this style of bulk-rock alteration involved interaction with relatively low -temperature seawater (halmyrolysis), which is similar to the style of alteration described from the upper pillow lavas of Hole 504B (Emmermann, 1985). In the subsequent discussion of the igneous geochemistry, the data have been screened for alteration, such that samples with $\mathrm{K}_{2} \mathrm{O}$ greater than $0.1 \%$ have been excluded.

\section{GEOCHEMICAL OVERVIEW}

The basalts in Hole $896 \mathrm{~A}$ are strongly depleted, moderately evolved mid-ocean ridge basalts (Alt, Kinoshita, Stokking, et al., 1993). The basalts are most similar to the Groups D and $D^{\prime}$ basalts described from Hole 504B (Table 2; Autio and Rhodes, 1983; Kempton et al., 1985; Emmermann, 1985). No compositions have as yet been identified that are similar to either the Group M or T basalts described from Hole 504B (Kempton et al., 1985). The drill hole provides a stratigraphy in the lava sequence that may have developed from multiple events of magma injection. Furthermore, each magma pulse may have been produced from a different source, by different degrees of partial melting or from melting columns of different shapes. It is there- 

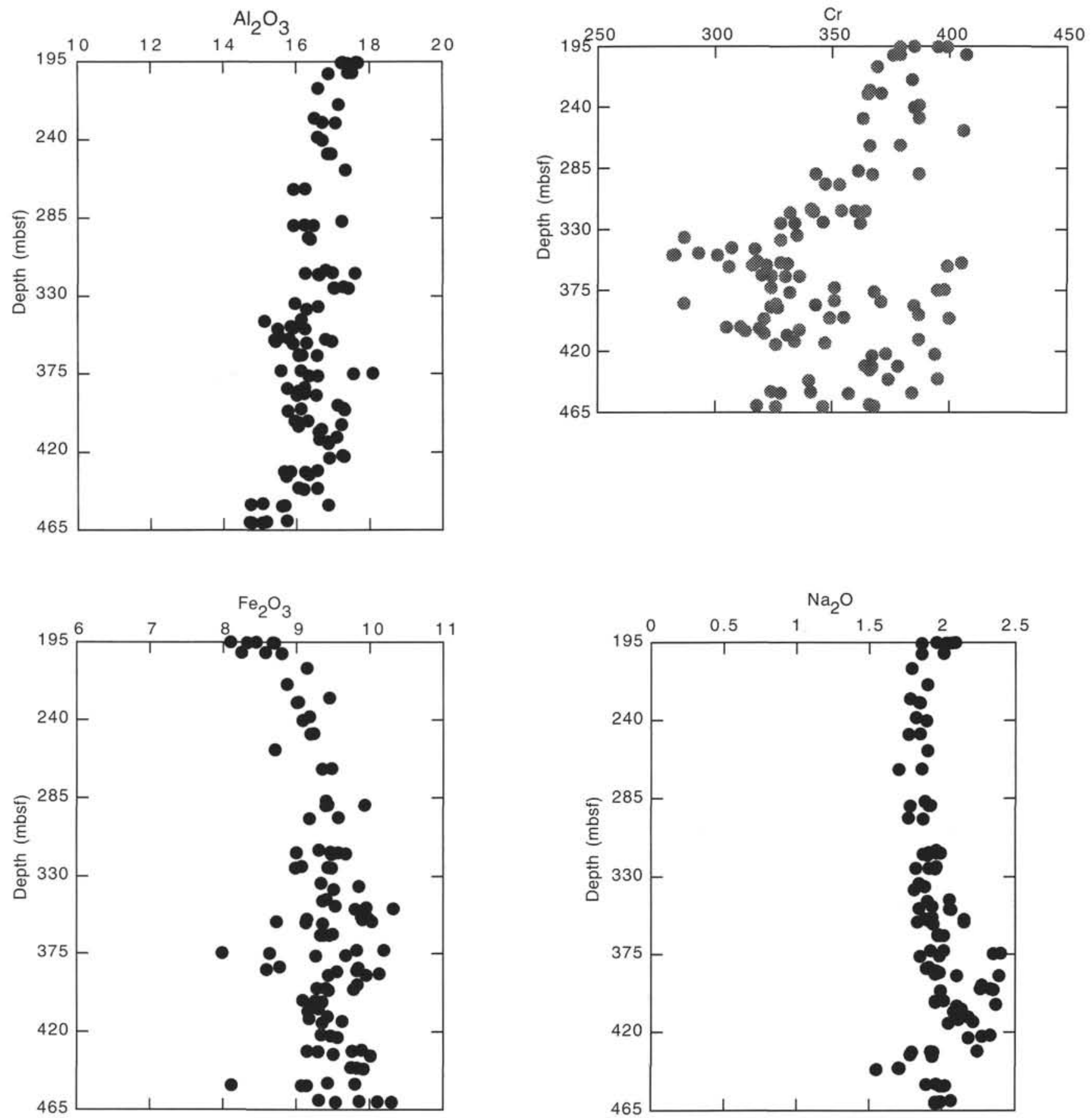

Figure 3. Oxide (wt\%) and elemental (ppm) variations downhole in Hole 896A.

fore, critical to establish whether any of the vertical geochemical variation (chemostratigraphy) is attributable to discrete magma batches before discussing the magmatic evolution of the basalt pile as a whole.

\section{CHEMOSTRATIGRAPHY}

Basalts from Hole 896A have a relatively restricted compositional range (Alt, Kinoshita, Stokking, et al., 1993), although within the hole there are significant changes in elemental concentrations with depth, which allows the identification of a number of chemical units.
The most abrupt change occurs at approximately 340 mbsf (Fig. 3). In the upper part of the hole, in Unit A (195.1-340 mbsf), the basalts have remarkably uniform compositions that are more depleted in $\mathrm{TiO}_{2}$ than are the Group D and D' basalts from Hole 504B (Table 2). The lower part of the hole ( $>340 \mathrm{mbsf}$ ) contains the following geochemical units (Fig. 3):

1. Unit B (340-391 mbsf) basalts show no significant variations in $\mathrm{TiO}_{2}, \mathrm{~V}$, and $\mathrm{Ni}$, but $\mathrm{Cr}$ decreases toward the top of the unit.

2. In Unit C (392-430 mbsf), concentrations of $\mathrm{TiO}_{2}, \mathrm{Cr}, \mathrm{Ni}$, and $\mathrm{V}$ all decrease systematically toward the top of this unit. 

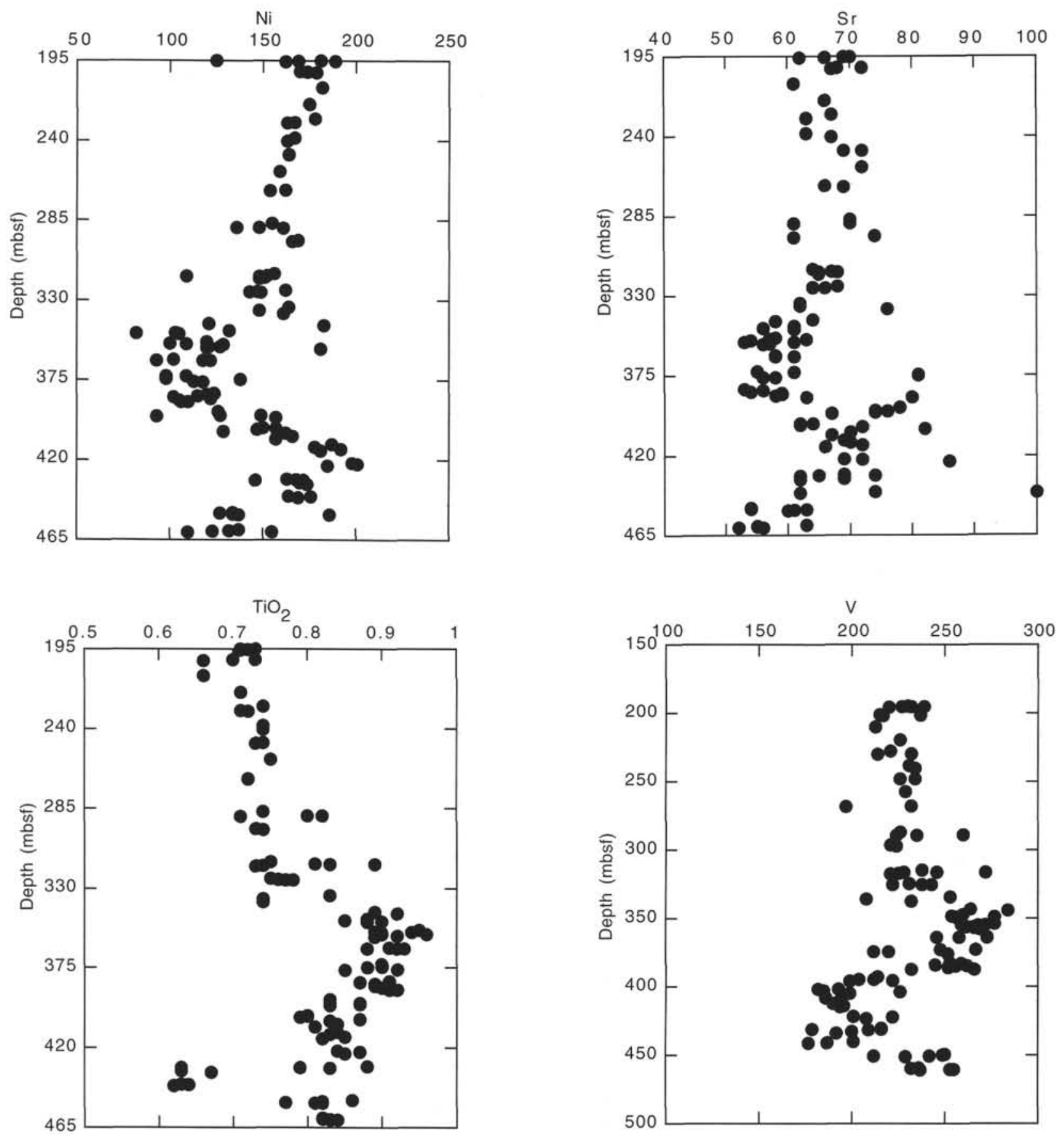

Figure 3 (continued).

3. Unit $\mathrm{D}(432-434 \mathrm{mbsf})$ basalts have the lowest $\mathrm{TiO}_{2}, \mathrm{Zr}$, and $\mathrm{Y}$ values in the lower part of the hole.

4. Unit E ( $434 \mathrm{mbsf}$ ) basalts have similar compositions to those in Unit B, except that the most primitive compositions occur at the top of this unit.

Incompatible trace element ratios, such as $\mathrm{K} / \mathrm{Ti}, \mathrm{Nb} / \mathrm{Zr}$, and $\mathrm{Rb} / \mathrm{Zr}$ can be used as indicators of mantle enrichment in ocean floor basalts, because these ratios do not vary greatly with either fractional crystallization and/or extensive partial melting (Sun and McDonough, 1989; Michael et al., 1994). Within Hole 896A the incompatible trace element ratios have a restricted range of values and show no systematic variations with depth, suggesting that the basalts were derived from a similar source. The sawtoothed elemental variations within the drilled section therefore, reflect variations produced by shallower level processes such as magma mixing and fractional crystallization.

In Unit A, the more primitive magmas occur at the top of the unit, suggesting an origin by magma mixing. In contrast, below $340 \mathrm{mbsf}$, the change in concentrations of $\mathrm{Ti}, \mathrm{V}, \mathrm{Cr}$, and $\mathrm{Ni}$ with depth defines a sawtoothed pattern (Fig. 3). This sawtoothed pattern may result from each unit representing the fractionation of a discrete magma batch, such that following the production of one unit, the magma chamber was replenished and then underwent fractionation. The replenishment introduced a new magma which initially produced rela- 

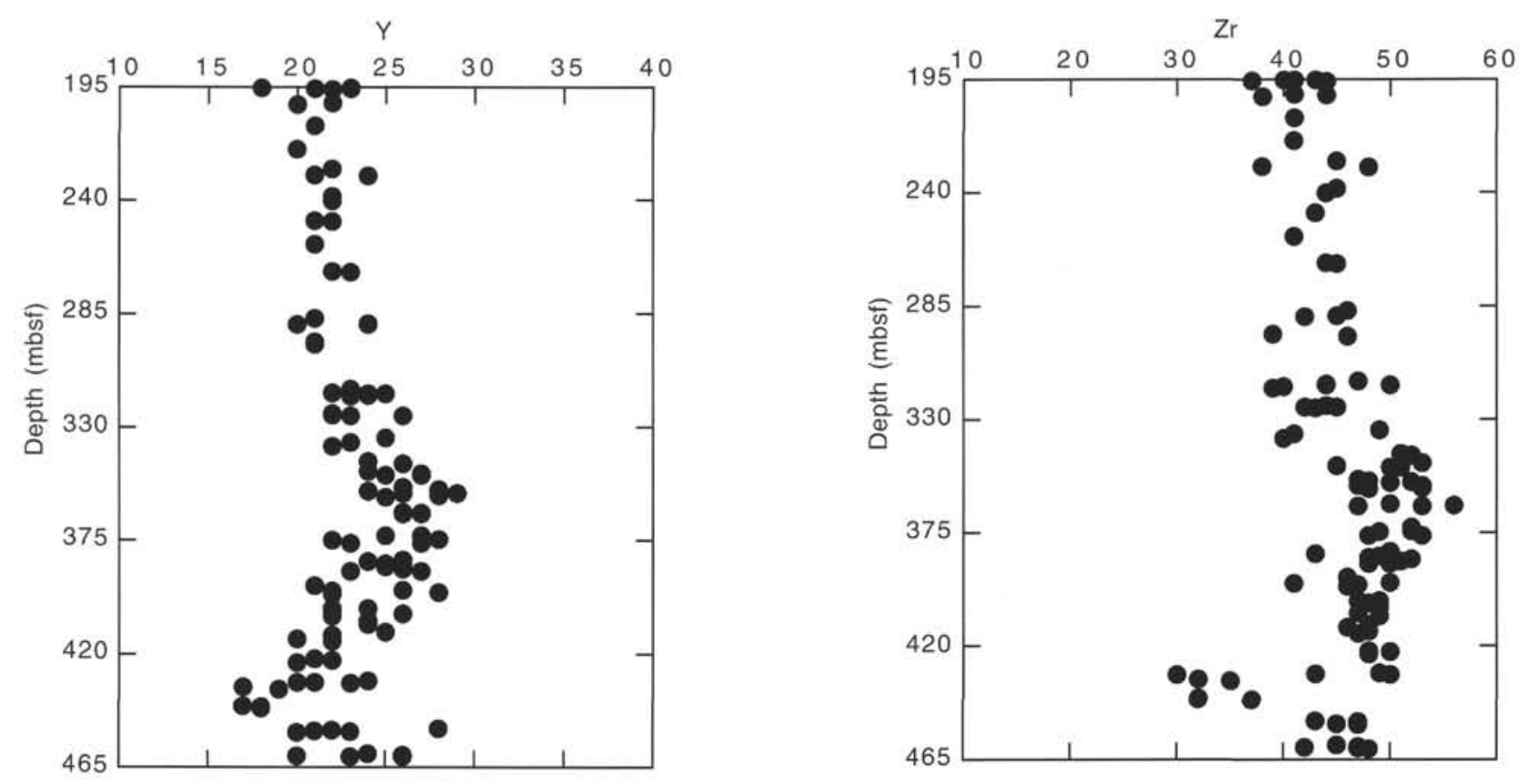

Figure 3 (continued).

tively primitive magmas and then more evolved magmas later. The one exception is Unit E, where the more primitive magmas are at the top of the unit, which indicates an origin by the mixing of magmas.

\section{COMPARISON WITH HOLE 504B}

Hole $896 \mathrm{~A}$ is situated approximately $\mathrm{I} \mathrm{km}$ to the south of Hole $504 \mathrm{~B}$, and assuming a spreading rate of $36 \mathrm{~mm} / \mathrm{yr}$ (Dick, Erzinger, Stokking, et al., 1992) is situated in crust $\sim 2.8 \times 104$ yr older than the Hole 504B basement. The majority of the volcanism associated with the Costa Rica Rift is situated in a $\sim 2 \mathrm{~km}$ wide neovolcanic zone (riftvalley) that is bounded by fault scarps (van Andel and Ballard, 1979). From the difference in age of the two sites, Hole 896A was near to the margin of the neovolcanic zone when the Hole 504B basement was forming. However, the proximity of the two hole does allow assessment of the short term variation in magmatic processes operating at the ridge. As a preliminary guide for such variation the chemostratigraphy of both holes has been constructed (Fig. 4); to facilitate correlation between the holes, all the depth values are expressed as depth into basement for each hole, assuming the basement was first encountered at $179 \mathrm{mbsf}$ in Hole 896A and $274.5 \mathrm{mbsf}$ in Hole 504B (Alt, Kinoshita, Stokking, et al., 1993).

The most significance difference between Holes 896A and 504B occurs in the upper $\sim 150 \mathrm{~m}$. In this region, Hole $896 \mathrm{~A}$ basalts have higher $\mathrm{Al}_{2} \mathrm{O}_{3}$ and $\mathrm{Ni}$ and lower $\mathrm{P}_{2} \mathrm{O}_{5}, \mathrm{TiO}_{2}, \mathrm{~V}, \mathrm{Y}$, and $\mathrm{Zr}$ values compared with Hole 504B basalts (Fig. 4). The upper $\sim 150 \mathrm{~m}$ of basement in Hole 504B is characterized by downhole sawtoothed profiles for $\mathrm{Ti}$ and $\mathrm{Cr}$; this region also contains the Group $\mathrm{M}$ and $\mathrm{T}$ basalts (Kempton et al., 1983). In Hole 896A, the upper $\sim 150 \mathrm{~m}$ of basement does not contain any sawtoothed element variations with depth. The sawtoothed profiles are the result of magma mixing, since in a normal fractionating sequence, the most primitive lavas occur at the base and the more evolved at the top, but by mixing of different magma batches it is possible to get the reverse (i.e., most evolved at base, most primitive at top) and so a saw-tooth profile is created within the lava pile. The implication from this data is that during the formation of Hole 504B lavas, the magma chamber was replenished relatively frequently with new (more primitive) magma batches, whereas during the formation of Hole 896A the magma chamber was not replenished on such a relatively short time scale. Below $\sim 150 \mathrm{~m}$ in the basement of both holes (Fig. 4), sawtoothed profiles are common, suggesting that the magma chambers were often replenished with new batches of undifferentiated magma.

\section{MAGMATIC EVOLUTION}

In Hole 896A, plagioclase and olivine are the major phenocryst phases and clinopyroxene has been reported only as a phenocryst phase between 351 and 391 mbsf (Alt, Kinoshita, Stokking, et al., 1993). Thus, the combination of potential fractionating assemblages can be modeled effectively on major element diagrams (Fig. 5). The following discussions limited to Units A, B and C, since the insufficient unaltered samples in Units D and E to draw any valid conclusions.

Unit $\mathrm{A}$ basalts ( $<340 \mathrm{mbsf}$ ) display negative correlations between $\mathrm{MgO}-\mathrm{CaO}$ and $\mathrm{MgO}-\mathrm{Al}_{2} \mathrm{O}_{3}$, which is consistent with the fractionation of plagioclase and or olivine (Fig. 5). Both $\mathrm{Ni}$ and $\mathrm{Cr}$ increase toward the top of this unit, indicating a reversed sequence, with the more evolved lavas at the base and the more primitive at top of the unit. Reversed magmatic trends result from magma mixing, which in the case of Hole $896 \mathrm{~A}$ was the result of mixing a new primitive magma with the evolved fractionated magma remaining in the high level magma chamber.

Overall, basalts from Units B and C display negative correlations between $\mathrm{MgO}-\mathrm{CaO}$ and $\mathrm{MgO}-\mathrm{Al}_{2} \mathrm{O}_{3}$, and there is a degree of scatter in the data (Fig. 5). This scatter is consistent with the participation of clinopyroxene in the fractionating assemblage (i.e., plagioclase + olivine + clinopyroxene). The involvement of clinopyroxene in the fractionating assemblage is consistent with the phenocryst assemblages described for these basalts (Alt, Kinoshita, Stokking, et al., 1993).

\section{DISCUSSION}

The chemostratigraphy for Hole $896 \mathrm{~A}$ is consistent with the derivation of different magma batches from a common source. However, 
significant high-level modification of individual magma batches has occurred by both fractional crystallization and magma mixing. The net result is chemostratigraphy, which reflects the dynamic nature of the magmatic systems. Thus, when viewed as a single entity, the basalts have a range of incompatible trace element concentrations at a given $\mathrm{MgO}$ value (Alt, Kinoshita, Stokking, et al., 1993), reflecting the variation of the magmatic processes with time.

There is no evidence to suggest a two-stage fractionation process for the lavas (Grove et al., 1992), but the variation in the nature of the fractionating phases (i.e., presence or absence of clinopyroxene) probably reflects magma chambers located at different levels within the crust or mantle. This model is similar to that proposed by Grove et al. (1992) and suggests that magma chambers on the Costa Rica Rift are dynamic features that shift their location in space and time. Further testing of such a model is being attempted by integrating data from the pillow lavas from Hole $504 \mathrm{~B}$, which is situated $\sim 1 \mathrm{~km}$ to the north of Hole $896 \mathrm{~A}$ in crust approximately $2.8 \times 10^{4} \mathrm{yr}$ younger than that at Hole 896A.

\section{ACKNOWLEDGMENTS}

The analyses used in this study were obtained while TSB was on staff at Nottingham University. NERC also provided funds for TSB to participate on Leg 148 and to attend the post-cruise meeting.

\section{REFERENCES}

Alt, J.C., Kinoshita, H., Stokking, L.B., et al., 1993. Proc. ODP, Init. Repts., 148: College Station, TX (Ocean Drilling Program).

Autio, L.K., and Rhodes, J.M., 1983. Costa Rica Rift Zone basalts: geochemical and experimental data from a possible example of multistage melting. In Cann, J.R., Langseth, M.G., Honnorez, J., Von Herzen, R.P., White, S.M., et al., Init. Repts. DSDP, 69: Washington (U.S. Govt. Printing Office), 729-745.

Dick, H.J.B., Erzinger, J., Stokking, L.B., et al., 1992. Proc. ODP, Init. Repts., 140: College Station, TX (Ocean Drilling Program).

Emmermann, R., 1985. Basement geochemistry, Hole 504B. In Anderson, R.N., Honnorez, J., Becker, K., et al., Init. Repts. DSDP. 83: Washington (U.S. Govt. Printing Office), 183-199.
Grove, T.L., Kinzler, R.J., and Bryan, W.B., 1992. Fractionation of midocean ridge basalt (MORB). In Morgan, J.P., Blackman, D.K., and Sinton, J.M. (Eds.), Mantle Flow and Melt Generation at Mid-Ocean Ridges. Geophys. Monogr., Am. Geophys. Union, 71:281-310.

Hellman, P.L., Smith, R.E., and Henderson, P., 1977. Rare earth element investigation of the Cliefden Outcrop, N.S.W., Australia. Contrib. Mineral. Petrol., 65:155-164.

Hey, R., Johnson, G.L., and Lowrie, A., 1977. Recent plate motions in the Galapagos area. Geol. Soc. Am. Bull., 88:1385-1403.

Holden, J.C., and Dietz, R.S., 1972. Galapagos Gore, NazCoPac Triple Junction and Carnegie/Cocos Ridges. Nature, 235:266-269.

Kempton, P.D., Autio, L.K., Rhodes, J.M., Holdaway, M.J., Dungan, M.A., and Johnson, P., 1985. Petrology of basalts from Hole 504B, Deep Sea Drilling Project, Leg 83. In Anderson, R.N., Honnorez, J., Becker, K., et al., Init. Repts. DSDP, 83: Washington (U.S. Govt. Printing Office), 129-164.

Lonsdale, P., and Klitgord, K.D., 1978. Structure and tectonic history of the eastern Panama Basin. Geol. Soc. Am. Bull., 89:981-999.

Michael, P.J., Forsyth, D.W., Blackman, D.K., Fox, P.J., Hanan, B.B., Harding, A.J., MacDonald, K.C., Neuman, G.A., Orcutt, J.A., Tolstoy, M., and Weiland, C.M., 1994. Mantle control of a dynamically evolving spreading centre: Mid-Atlantic Ridge $31-34^{\circ}$ S. Earth Planet. Sci. Lett., 121:451-468.

Sun, S.-S., and McDonough, W.F., 1989. Chemical and isotopic systematics of oceanic basalts: implications for mantle composition and processes. In Saunders, A.D., and Norry, M.J. (Eds.), Magmatism in the Ocean Basins. Geol. Soc. Spec. Publ. London, 42:313-345.

Tual, E., Jahn, B.M., Bougault, H., and Joron, J.L., 1985. Geochemistry of basalts from Hole 504B, Leg 83, Costa Rica Rift. In Anderson, R.N., Honnorez, J., Becker, K., et al., Init. Repts. DSDP. 83: Washington (U.S. Govt. Printing Office), 201-214.

Van Andel, T.H., and Ballard, R.D., 1979. The Galapagos Rift at $86^{\circ} \mathrm{W}: 2$. Volcanism, structure and evolution of the rift valley. J. Geophys. Res., 84:5379-5406.

Date of initial receipt: 8 August 1994

Date of acceptance: 21 July 1995

Ms 148SR-101 

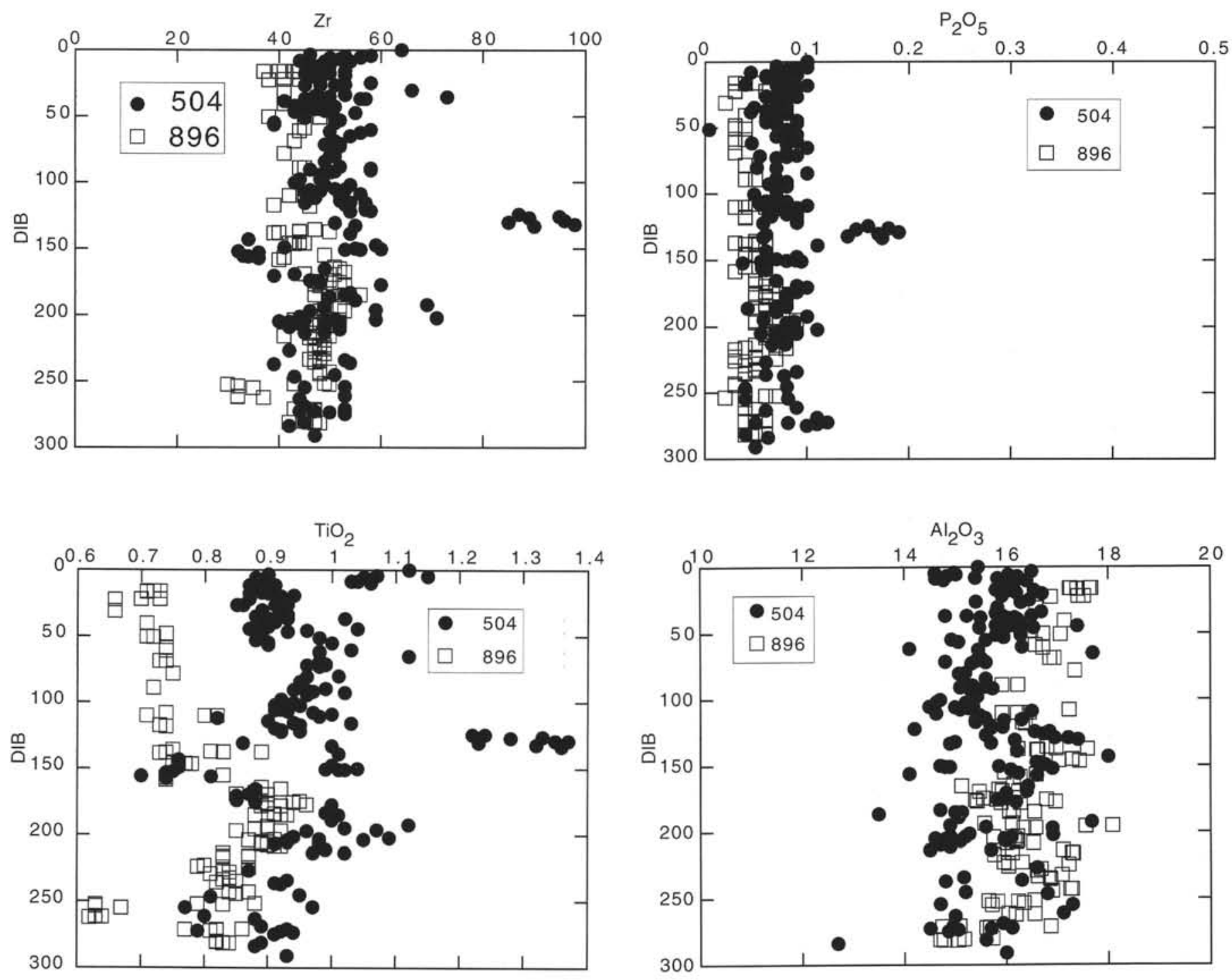

Figure 4. Oxide (wt\%) and elemental variations within Holes 896A and 504B. The depth scale is expressed as depth into basement (DIB) to allow direct comparison between the two holes. Data for Hole 504B from Emmermann (1985), Kempton et al. (1985), and Tual et al. (1985). 

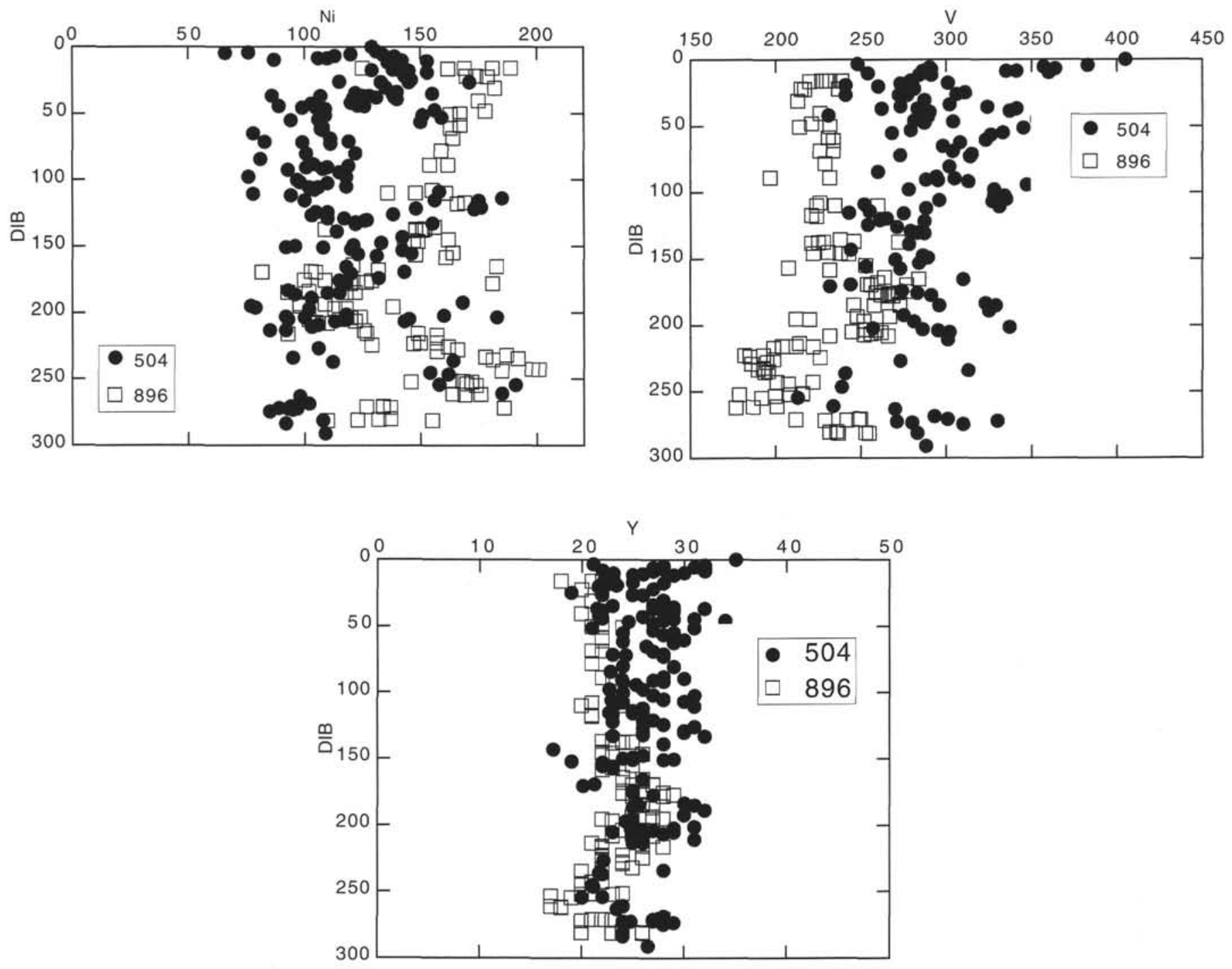

Figure 4 (continued).
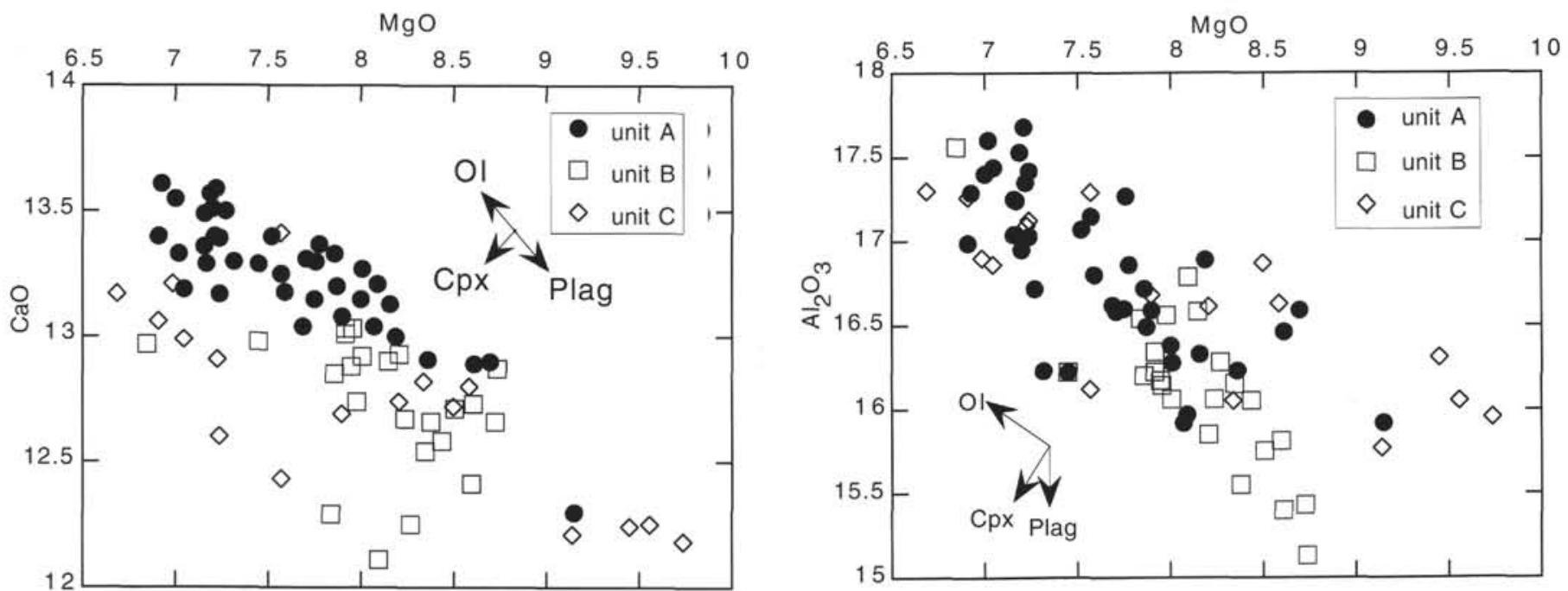

Figure 5. $\mathrm{MgO}$ vs. $\mathrm{CaO}$ and $\mathrm{Al}_{2} \mathrm{O}_{3}$ for basalts from Hole 896A. Fractionation vectors calculated for olivine (OI), plagioclase (Plag), and clinopyroxene (Cpx). 